\section{Some Herbage Responses to Fire on Pine-Wiregrass Range ${ }^{1}$}

\section{CLIFFORD E. LEWIS AND RICHARD H. HART ${ }^{2}$}

Associate Range Scientist, Southeastern Forest Experiment Station, Forest Service; and Research Agronomist, Agricultural Research Service, U. S. Department of Agriculture, Tifton, Georgia.

\section{Highlight}

Protecting two sites on pine-wiregrass range from fire caused a rapid reduction in herbage yields. Reintroducing fire on these sites resulted in significantly increased yields, but removal of old growth by hand clipping instead of burning caused a decrease in yield on the site with Olustee sand and an increase in yield on the site with Plummer sand. Although gallberry cover did not recover as rapidly after burning on the Olustee site as on the Plummer site, covariance analysis indicated that these differences in recovery did not fully account for the disparity in yield between burned and clipped plots on the two sites.

The use of fire in land management has vacillated over the years bctwcen full acceptability and unacceptability. Indiscriminate or destructive use of fire has at times given it a bad name, although in other situations it is proclaimed as a valuable tool. No doubt these conflicting views arise because of the way fire has been used and the differing responses to burning of various plant communities or plant species. A primary need, it seems, is to examine plant responses to fire in differing plant communities.

For many years, prescribed burning has been suggested as a major factor in promoting and maintaining high forage yields in the South (Wahlenberg et al., 1939; Halls et al., 1952; Duvall, 1962). And without it, many wiregrass species have been reported to become decadent with a reduction in ground cover (Halls et al., 1952 and 1956; Lemon, 1949; Hilmon and Hughes, 1965). Fire supposedly benefits plant growth by increasing organic matter, mineral elements, and nitrogen in the soil (Metz et al., 1961; Ahlgren and Ahlgren, 1960; Heyward and Barnette, 1934). However, Grelen and Epps (1967) concluded that litter removal on pine-bluestem range, either by mowing and raking or by burning, was the major cause of increased

\footnotetext{
${ }^{1}$ Cooperative investigations conducted by the Southeastern Forest Experiment Station, Forest Service; Crops Research Division, Agricultural Research Service, U. S. Department of Agriculture; and the Georgia Coastal Plain Experiment Station. University of Georgia, College of Agriculture, Coastal Plain Experiment Station Journal Series Paper No. 857. Received July 21, 1971.

${ }^{2}$ Present address is Plant Industry Station, Beltsville, Maryland.
}

yields and improved quality of forage, primarily pinehill bluestem (Andropogon divergens (Hack.) Andress. ex Hitcht.) and slender bluestem (A. tener (Nees) Kunth.).

Fire has also proved valuable in slowing down gallberry (Ilex glabra (L.) A. Gray) growth (Hughes and Knox, 1964), killing understory hardwoods (Lotti et al., 1960), and, in combination with herbicides, in killing saw-palmetto (Serenoa repens (Bartr.) Small) and gallberry (Burton and Hughes, 1961; Altobellis and Hough, 1968). These treatments increased forage yields, presumably by reducing canopy cover, which affects penetration of sunlight, and reducing plant competition for soil moisture and nutrients. Canopy cover, as a measure of competition, has been shown to influence forage yields (Halls et al., 1956; Halls and Schuster, 1965; Hart et al., 1970). Shading alone has been found to reduce growth of many southern plants (Burton and Knox, 1959; Hart et al., 1970; Harshbarger and Perkins, 1971). Without burning, gallberry, a major noxious shrub in the pine-wiregrass type, becomes large and robust, thereby shading much of the ground. Therefore, burning to provide temporary reduction in shading by gallberry and other shrubs could be expected to increase yields of herbaceous plants.

To further determine the effects of fire, an investigation was conducted on two south Georgia sites with differing soils and vegetation. Data was collected to measure (1) the trend in forage yields with fire exclusion for a number of years, (2) the effect on yields of reintroducing fire as compared to litter removal by hand clipping, and (3) the relationship between gallberry cover and herbage yield.

\section{Study Area and Design}

The investigation was conducted at two sites with pinewiregrass vegetation on the Alapaha Experimental Range, Berrien County, Georgia, in the Lower Coastal Plain. The site with Olustee fine sand differed from that with Plummer sand by being wetter and devoid of pineland threeawn (Aristida stricta Michx.). Common forage plants occurring on both sites werc Curtiss dropsced (Sporobolus curtissii (Vasey) Small ex Scribn.), bluestem grasses (Andropogon spp.), panicum grasses (Panicum spp.), toothachegrass (Ctenium aromaticum (Walt.) Wood), and several forbs and grasslikes. The elevation is about 290 feet, and rainfall averages about 46 inches per year, of which 32 inches fall during the growing season of March through September.

Both sites had previously been used for testing fire and herbicides to control gallberry. The last such treatment on the Olustee site was in 1956, and the last treatment on the Plummer site was in 1959. These treatments resulted in a wide range of brush densities on the various plots at each site, but the stands of gallberry were similar on both sites. Herbage that had been clipped periodically to determine yields had been returned to each plot in order to simulate buildup of litter. 


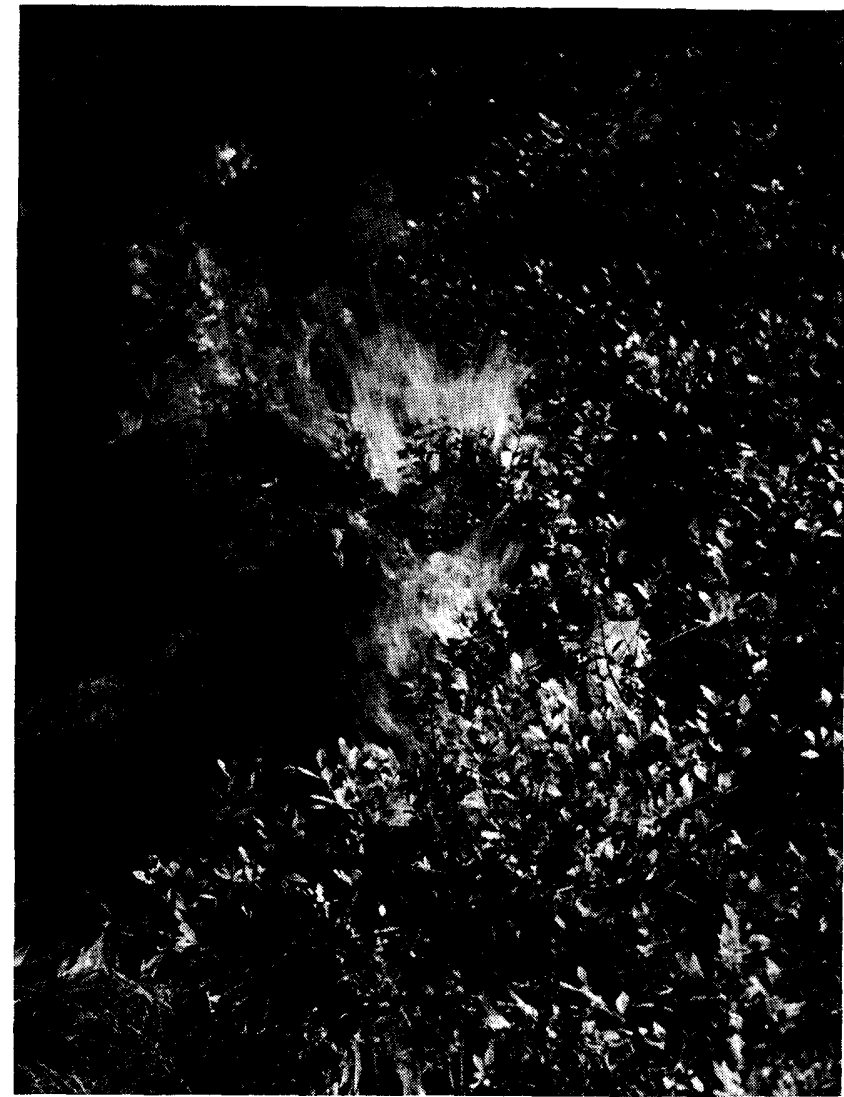

Fic. 1. Burning pine-wiregrass range on the site with Plummer sand in 1965. All herbage was consumed and stems of gallberry were burned to the ground.

Half of the study plots on each site were burned and half were left unburned but hand clipped to remove all herbaceous material. On the Olustee site, a completely randomized design of 38 burned and 38 unburned plots was used. On the Plummer site, a randomized complete block design with three replications was used. Half of each block was burncd and the other half left unburned, and each contained 18 sample plots. These designs were required because of the earlier fire-herbicide studies.

Fire was applied to assigned plots in February 1964 on the Olustee site and in January 1965 on the Plummer site

Table 1. Rainfall (inches) during the growing season (March through September) and annual herbage yields (lb./acre) during selected years while the two sites were protected from fire. 1

\begin{tabular}{lcccccc}
\hline \hline & & \multicolumn{2}{c}{ Olustee site } & & \multicolumn{2}{c}{ Plummer site } \\
Year & Rainfall & $\begin{array}{c}\text { Years of } \\
\text { protection }\end{array}$ & Yield & & $\begin{array}{c}\text { Years of } \\
\text { protection }\end{array}$ & Yield \\
\hline 1958 & 30.9 & 2 & $1440^{\mathrm{a}}$ & - & - \\
1960 & 29.3 & 4 & $860^{\mathrm{b}}$ & 1 & $1760^{\mathrm{a}}$ \\
1961 & 29.5 & - & - & 2 & $1640^{\mathrm{b}}$ \\
1962 & 21.2 & 6 & $840^{\mathrm{b}}$ & 3 & $1360^{\mathrm{c}}$ \\
\hline
\end{tabular}

1 Yields within a column marked with different superscripts arc significantly different $(\mathbf{P}<.01)$.
(Fig. 1). On the unburned plots, the litter (old dead growth and live topgrowth) of herbaceous plants was clipped 1 inch above ground and removed from the plot in order to facilitate easy recognition of the current year's growth of herbage and to ensure that all plots were similar in relation to accumulated litter. Gallberry was left undisturbed on the clipped plots.

Measurements of vegetation were made in October after treatment. Herbage yield was sampled on permanent 9.6- $\mathrm{ft}^{2}$ subplots established in the previous studies. The current growth of five species of categories was clipped about 1 inch above ground on each subplot. All samples were oven dried at $70 \mathrm{C}$ to determine dry-matter yields. Before treatment and when yields were determined, average height of gallberry was determined, stems per $9.6-\mathrm{ft}^{2}$ subplot were counted, and percentage of ground cover was estimated on each plot.

\section{Results and Discussion}

\section{Fire Protection}

Before fire was applied, increased gallberry cover and litter accumulation both contributed to reduced herbage yields (Table 1 ). The reduction in yield between the second and fourth years on the Olustee site averaged 295 pounds per year, which was about the same that occurred between the second and third years on the Plummer site. Therefore, these data indicate that trends in yearly re duction in yield were similar on both sites but that the Plummer site was inherently more productive than the Olustee site.

Rainfall during the growing seasons when yields were measured was slightly less than average. However, even though the rainfall in 1962 was considerably less, it did not have a drastic effect on yields.

\section{Reintroduction of Fire}

After reintroduction of burning, yields of total herbage increased significantly $(\mathrm{P}<.01)$ on both sites (Table 2) over those last measured under fire protection (Table 1). But litter removal by clipping produced a similar significant increase $(\mathrm{P}<$ $.01)$ on the Plummer site, while on the Olustee site yields declined significantly $(\mathrm{P}<.05)$ after clipping. This lack of consistency on the two sites is puzzling and suggests that factors other than litter removal by clipping or burning influence yields. Rainfall during the growing season measured 42 inches in 1964 and 37 inches in 1965. That both accumulations were greater than the long-term average or the accumulation in 1962 could explain some of the increases in yields. However, the continued decline after clipping on the Olustee site indicates that rainfall was not the major factor influencing yields.

Herbage yields by individual species or groups were generally greater after burning than after clipping, although these differences were seldom statistically significant (Table 2). Bluestem grasses were the only plants that yielded more after clip- 
Table 2. Herbage yields (lb./acre) measured the following October after reintroducing fire and clipping in February 1964 on the Olustee site and in January 1965 on the Plummer site.

\begin{tabular}{|c|c|c|c|c|c|c|}
\hline \multirow[b]{2}{*}{ Species } & \multicolumn{3}{|c|}{ Yield on Olustee site } & \multicolumn{3}{|c|}{ Yield on Plummer site } \\
\hline & Burned & Clipped & Difference $^{1}$ & Burned & Clipped & Difference $^{1}$ \\
\hline Pineland threeawn & $(2)$ & $(2)$ & $\left({ }^{2}\right)$ & 450 & 380 & $70^{\mathrm{ns}}$ \\
\hline Curtiss dropseed & 460 & 360 & $100^{\mathrm{ns}}$ & 610 & 600 & $10^{\mathrm{ns}}$ \\
\hline Bluestem grasses & 300 & 180 & $120 * *$ & 260 & 330 & $-70^{\mathrm{ns}}$ \\
\hline Other grasses & 80 & 80 & $0^{\mathrm{ns}}$ & 300 & 300 & $0^{\mathrm{ns}}$ \\
\hline Other herbage & 180 & 80 & $100^{*}$ & 300 & 220 & $80^{\mathrm{ns}}$ \\
\hline Total & 1020 & 700 & $320 * *$ & 1920 & 1830 & $90^{\mathrm{ns}}$ \\
\hline
\end{tabular}

1 ns $=$ Not significant at $\mathbf{P}>.10$.

$*$ Significant at $\mathbf{P}<.07$.

** = Significant at $\mathrm{P}<.01$.

${ }^{2}$ Species too sparse to sample separately.

ping than after burning, but this response occurred only on the Plummer site.

Measurements of gallberry before treatment indicated that no significant differences in cover or number of stems existed between the plots selected for burning and those selected for clipping. Stands of gallberry were similar and of wide range on both sites, although the gallberry on the Olustee site was older and taller and had slightly greater ground cover and fewer stems. On both sites, the burned and clipped plots exhibited the same range of conditions in approximately equal proportions. When (1) gallberry cover before treatment, (2) gallberry cover after treatment, and (3) number of stems before treatment were used as covariates, adjusting yields by covariance analyses had little effect on yields; therefore, only the unadjusted means were presented in Table 2. These analyscs indicated that the differences in yield between the burned and clipped plots were true effects and could not be attributed solely to differences in gallberry cover or number of stems.

Gallberry is a shrub which resprouts from underground rootstock. On both sitcs, all gallberry stems on the burned plots were killed to ground level,

Table 3. Height (inches), number of stems per 9.6-ft ${ }^{2}$ plot, and ground cover $(\%)$ of gallberry the following October after burning in February 1964 on the Olustee site and in January 1965 on the Plummer site.

\begin{tabular}{clccc}
\hline \hline Site & Treatment & Height $^{1}$ & Stems $^{1}$ & Cover $^{1}$ \\
\hline Olustee & Burned & $15^{\mathrm{a}}$ & $24^{\mathrm{a}}$ & $18^{\mathrm{a}}$ \\
& Unburned $^{2}$ & $28^{\mathrm{b}}$ & $10^{\mathrm{b}}$ & $26^{\mathrm{b}}$ \\
\multirow{3}{*}{ Plummer } & Burned $^{\mathrm{b}}$ & $18^{\mathrm{a}}$ & $35^{\mathrm{a}}$ & $22^{\mathrm{a}}$ \\
& Unburned $^{2}$ & $30^{\mathrm{b}}$ & $24^{\mathrm{a}}$ & $23^{\mathrm{a}}$ \\
\hline
\end{tabular}

${ }^{1}$ Within a site, means marked with different superscripts in the same column are significantly different $(P<.05)$.

${ }^{2}$ Herbage was hand clipped from these plots at the time of burning, but the gallberry was undisturbed. but within 9 months they were about one-half as tall as the unburned stems (Table 3). On the Olustee site, number of stems was significantly greater and ground cover was significantly less on the burned than on the unburned plots. These changes in height, numbers, and cover followed the pattern observed by Hughes and Knox (1964). However, on the Plummer site, there were no significant differences in number of stems or ground cover; the gallberry had fully recovered the first year after burning.

Fire has only a tcmporary effect in controlling gallberry and the differing responses of gallberry on the two sites may offer a partial explanation for the differing yield responses on the two sites. Because gallberry cover is directly related to yields, as will be shown later, the more rapid recovery from burning may have prevented significant differences in yield from developing between the burned and clipped plots on the Plummer site.

\section{Shrub-Herbage Relationships}

Because the vegetation on the Plummer site was more typical of the upland areas of the pine-wiregrass type, the effects on herbage yield of gallberry cover and number of stems were analyzed by correlation-regression methods (Table 4). As gallberry cover increased, herbage yields decreased; the correlation coefficient from unburned plots was slightly better than that from burned plots. The regression equations for burned and unburned plots were similar but indicated the slightly greater yield obtained from burned plots.

Herbage yields were also significantly correlated with the number of gallberry stems on unburned plots but were not significantly correlated on burned plots. On both, yields decreased as the number of stems increased.

When data from the unburned plots were used, the multiple lincar regression of yicld on gallbcrry 
Table 4. Regression equations and correlation coefficients for examining linear relationships of herbage yield on gallberry cover and number of stems from burned and unburned plots.

\begin{tabular}{lllccc}
\hline \hline $\begin{array}{l}\text { Independent } \\
\text { variable }\end{array}$ & Treatment & $\begin{array}{c}\text { Regression } \\
\text { equation }\end{array}$ & $\begin{array}{c}\text { Standard } \\
\text { error }\end{array}$ & $\begin{array}{c}\text { Correlation } \\
\text { coefficient }\end{array}$ & $\begin{array}{c}\text { Signifi- } \\
\text { cance }^{2}\end{array}$ \\
\hline Cover $(\%)$ & Unburned & $\mathrm{Y}=2273-20 \mathrm{X}$ & 465 & -0.50 & $*{ }^{*}$ \\
& Burned & $\mathrm{Y}=2289-17 \mathrm{X}$ & 452 & -0.32 & $* *$ \\
Stems (No.) & Unburned & $\mathrm{Y}=2167-15 \mathrm{X}$ & 494 & -0.39 & $* *$ \\
& Burned & $\mathrm{Y}=1999-2 \mathrm{X}$ & 475 & -0.11 & $\mathrm{~ns}$ \\
\hline
\end{tabular}

\footnotetext{
154 observations in each equation.

${ }^{2} \mathrm{~ns}=$ Not significant $(\mathrm{P}>.05)$.

$*^{* *}=$ Significant $(\mathrm{P}<.01)$.
}

cover and number of stems failed to give a significantly better fit $(R=0.51)$ than the linear regression of yield on cover. The regression lines were similarly located. It appears from these data that gallberry cover is a better measure of plant competition than is the number of gallberry stems.

Scatter diagrams showed that yields of pineland threeawn, Curtiss dropseed, bluestem grasses, and forbs decreased with increasing gallberry cover on unburned plots. However, yields of other grasses on both burned and unburned plots and of forbs on burned plots showed no association with gallberry cover.

\section{Conclusions}

Pine-wiregrass ranges become unproductive with long-term protection from fire. Increasing tree and brush cover is a factor in reducing yields, but the change in species composition and a reduction in basal area of forage species indicate also that wiregrass species deteriorate without burning. Reductions in yields on two sites protected from fire for 6 and 8 years showed that herbage yield can quickly be cut in half.

Reintroducing fire on range that had not been burned for several years significantly increased forage yield. But litter removal by hand clipping and raking boosted yields only on the Plummer site. Yields were increased by burning but continued to decline with clipping on the Olustee site. If such different responses can be obtained on two sites within one-half mile of each other, similar influences are probably exerted on many sites with similar soils and vegetation throughout the South. Such influences may account for conflicting reports in the literature.

Forage yields decreased as ground cover increased, a response that occurred on both unburned and recently burned plots. After burning, gallberry was reduced in size and ground cover, but many new stems sprouted from rootstocks and cover soon returned. On one site the recovery of ground cover was more rapid than on the other site.

There are many benefits claimed for prescribed burning in pine-wiregrass ranges. One of these, increased yields, appears to be valid, especially on certain sites. In view of the fact that contradictory results were obtained after litter removal by clipping and raking on the two sites in the present study, burning should continue to be used as a standard practice for range improvement on pinewiregrass ranges.

\section{Literature Cited}

Ahlgren, I. F., and C. E. Ahlgren. 1960. Ecological effects of forest fires. Bot. Rev. 26:483-533.

Altobellis, A. T., ANd W. A. Hough. 1968. Controlling palmetto with fire and herbicides. Ga. Forest Res. Counc. Res. Pap. 52. 4 p.

Burton, G. W., AND F. E. Knox. 1959. The influence of light reduction upon the production, persistence and chemical composition of Coastal bermudagrass, Cynodon dactylon. Agron. J. 51:537-542.

Burton, G. W., AND R. H. Hughes. 1961. Effects of burning and 2,4,5-T on gallberry and saw-palmetto. J. Forest. 59:497-500.

DuvalL, V. L. 1962. Burning and grazing increase herbage on slender bluestem range. J. Range Manage. 15:14-16.

Grelen, H. E., and E. A. Epps, Jr. 1967. Herbage responses to fire and litter removal on southern bluestem range. J. Range Manage. 20:403-404.

Halls, L. K., O. M. Hale, and B. L. Southwell. 1956. Grazing capacity of wiregrass-pine ranges of Georgia. Ga. Agr. Exp. Sta. Tech. Bull. N. S. 2. 38 p.

Halls, L. K., and J. L. Schuster. 1965. Tree-herbage relations in pine-hardwood forests of Texas. J. Forest. 63:282-283.

Halls, L. K., B. L. Southwell, and F. E. Knox. 1952. Burning and grazing in Coastal Plain forests. Ga. Agr. Exp. Sta. Bull. 51.33 p.

Harshbarger, T. J., and C. J. Perkins. 1971. Effect of shade on growth and seed production of partridgepea. J. Wildlife Manage. 35:382-385.

Hart, R. H., R. H. Hughes, C. E. Lewis, and W. G. Monson. 1970. Effect of nitrogen and shading on yield and quality of grasses grown under young slash pine. Agron. J. 52:285-287.

Heyward, F., and R. M. Barnette. 1934. The effect of frequent fires on the chemical composition of forest soils in the longleaf pine region. Fla. Agr. Exp. Sta. Bull. 265. 39 p. 
Hilmon, J. B., ANd R. H. Hughes. 1965. Forest Service research on the use of fire in livestock management in the South. Fourth Annu. Tall Timbers Fire Ecol. Conf. Proc. 1965:260-275.

Hughes, R. H., AND F. E. Knox. 1964. Response of gallberry to seasonal burning. Southeast. Forest Exp. Sta., U. S. Forest Serv. Res. Note SE-21. 3 p.

Lemon, P. C. 1949. Successional responses of herbs in the longleaf-slash pine forest after fire. Ecology 30:135-145. Lotti, T., R. $\Lambda$. Klawitter, And W. P. LeGrande. 1960.
Prescribed burning for understory control. U. S. Forest Serv. Southeast. Forest Exp. Sta. Pap. 116. 19 p.

Metz, L. J., T. Lotti, ANd R. A. Klawitter. 1961. Some effects of prescribed burning on Coastal Plain forest soil. U. S. Forest Serv., Southeast. Forest Exp. Sta. Pap. 133. $10 \mathrm{p}$.

Wahlenterg, W. G., S. W. Greene, and H. R. Reed. 1939. Effects of fire and cattle grazing on longleaf pine lands as studied at McNeill, Mississippi. U. S. Dep. Agr. Tech. Bull. 683. 52 p. 